\title{
Welcome to New Year 2014 in the Polish Archives of Internal Medicine (Pol Arch Med Wewn)
}

\author{
Anetta Undas \\ Editor-in-Chief, Polish Archives of Internal Medicine
}

\section{Correspondence to:}

Prof. Anetta Undas, MD, PhD, Instytut Kardiologii, Uniwersytet Jagielloński, Collegium Medicum, ul. Prądnicka 80, 31-202 Kraków, Poland, phone: + 48-12-614-30-04 fax: +48-12-423-39-00, e-mail: mmundas@cyf-kr.edu.pl Received: February 3, 2014 Accepted: February 3, 2014 Conflict of interest: none declared. Pol Arch Med Wewn. 2014; $124(1-2): 5-6$

Copyright by Medycyna Praktyczna, Kraków 2014
The year 2013 was a good year for the Polish Archives of Internal Medicine (Pol Arch Med Wewn), the official journal of the Polish Society of Internal Medicine. Our journal has made substantial progress over the last year, as highlighted by an increased impact factor of 1.833 , reported in June 2013, ${ }^{1}$ which has placed it among the top-ranking Polish life science journals. Over a long history of the Pol Arch Med Wewn (the 90th anniversary of the first issue has been celebrated in 2013), ${ }^{2}$ the journal has been "reactivated" proving the significance of internal medicine in Poland and other countries despite the pressure of highly specialized medicine. All this would not have been possible without interesting, well-written papers submitted by our authors and the critical insights provided by our reviewers. Our challenge is to continue to work even harder to further improve the standing of the Pol Arch Med Wewn.

I am aware of the fact that remarkable journal proliferation observed in recent years has resulted in an increased impact factor of a vast majority of the major journals, especially those that publish mainly review articles and not original contributions. The aim of the Pol Arch Med Wewn is to maintain a large proportion of original articles among the published papers.

In 2013, we published 53 original articles, 21 reviews, 15 letters to the editor, and 21 clinical images. In 2013, we introduced the "Clinical Images" section, which allowed us to publish several interesting and quite diverse reports, which have been very well received by our readers. We also strongly promote our "Letter to the Editor" section as a place for a sort of "post-publication peer review" encompassing insightful comments and suggestions in reference to the published research papers. This type of articles provides a good opportunity for readers to share their views on how a given article impacts the field. As most researchers in the academic world, I have experienced the exercise of power to quiet a debate rather than support it. We welcome all our readers who want to ask difficult questions and challenge the conclusions drawn by the authors, and whose opinions about the published papers are informed and grounded in science, and encourage them to submit letters to the Editor. Similarly, original articles published in our journal should present novel controversial findings supported by sound methodology. To my view, promoting the best science means to support different opinions and uncertainty as well as to provide pages for contributions that address, or even cause, controversy.

The number of submissions in 2013 reached 341. As a direct result of the increasing number of high-quality papers being submitted, the time from submission to publication has been observed to increase significantly in many journals in recent years, resulting in a delay of more than 6 months from acceptance to publication in print. We are proud of having an average turnaround time from submission to the first editorial decision with reviewers' comments of 15 days (21 days in 2012) and to the final decision of 36 days (41 days in 2012). Other statistics calculated for all articles published in 2013 are as follows: time from submission to online-first publication of 56 days and to print publication of 86 days. In 2013, we published 121 articles. Of note, our overall acceptance rate substantially decreased to $24.6 \%$ in 2013 . It is now our primary goal to maintain such impressive results in 2014 . We will continue to focus on improving the quality of our journal as well as its 2013 impact factor, which is currently estimated at 1.9 .

All our authors directly contribute to the quality of the Pol Arch Med Wewn. The top cited articles published in 2013 include original papers that have cross-disciplinary impact and review papers, which are usually cited about twice the average, 
TABLE 1 Most cited papers published in 2013

\begin{tabular}{l}
\hline Janda K, et al. ${ }^{3}$ \\
\hline Szpak D, et al. ${ }^{4}$ \\
\hline Pietruszyński R, et al. $^{5}$ \\
\hline Nehring P, et al. ${ }^{6}$ \\
\hline Rechciński T, et al. ${ }^{7}$ \\
\hline Sarr MG ${ }^{8}$ \\
\hline
\end{tabular}

TABLE 2 Top reviewers in 2013

\begin{tabular}{l}
\hline Prof. Jolanta Małyszko, MD, PhD \\
\hline Prof. Tomasz Stompór, MD, PhD \\
\hline Jarosław Zalewski, MD, PhD \\
\hline Anna Bednarek-Skublewska, MD, PhD \\
\hline Prof. Stanisław Czekalski, MD, PhD \\
\hline Piotr Nehring, MD, PhD \\
\hline
\end{tabular}

TABLE 3 New members of the National Scientific Board

\begin{tabular}{cc} 
Member & Affiliation \\
$\begin{array}{c}\text { Prof. Tomasz Brzozowski, } \\
\text { MD, PhD }\end{array}$ & $\begin{array}{c}\text { Department of Physiology, Jagiellonian University } \\
\text { Medical College, Kraków, Poland }\end{array}$ \\
\hline $\begin{array}{c}\text { Artur Dziewierz, } \\
\text { MD, PhD }\end{array}$ & $\begin{array}{c}\text { 2nd Department of Cardiology, Jagiellonian University } \\
\text { Medical College, Kraków, Poland }\end{array}$ \\
\hline $\begin{array}{c}\text { Prof. Piotr Głuszko, } \\
\text { MD, PhD }\end{array}$ & $\begin{array}{c}\text { Department of Clinical Rheumatology, Institute } \\
\text { of Rheumatology, Warsaw, Poland }\end{array}$ \\
\hline $\begin{array}{c}\text { Prof. Krzysztof Strojek, } \\
\text { MD, PhD }\end{array}$ & $\begin{array}{c}\text { Silesian Centre of Heart Diseases, Zabrze, Poland } \\
\text { Prof. Dorota }\end{array}$ \\
$\begin{array}{c}\text { Zozulińska-Ziótkiewicz, } \\
\text { MD, PhD }\end{array}$ & $\begin{array}{c}\text { Department of Internal Medicine and Diabetology, } \\
\text { Poznan University of Medical Sciences, Raszeja } \\
\text { Hospital, Poznań, Poland }\end{array}$ \\
\hline
\end{tabular}

and this is consistent with most journals. The articles that received most attention in 2013 are listed in TABLE 1.3-9

In the July-August 2013 issue of our journal, 3 best student papers were published. ${ }^{10-12} \mathrm{I}$ am particularly proud of this unique initiative. Its goal is to enable hard-working and talented medical students to present their research to the scientific community and see their first article in print in a journal with an impact factor. I hope that the award winners will be the much-needed future leaders of life science in Poland. The third edition of the student awards has been announced and the deadline for article submission is March 15, 2014.

Of special value is the contribution of several reviewers who have helped us select the best research articles and, by providing valuable comments, greatly improved their quality before final publication. Our 2013 top reviewers' are listed in TABLE 2. I hope that our reviewers will help us remain competitive in terms of publishing the best articles by continuing to provide critical reviews in a timely manner. We are willing to respond to presubmission inquiries regarding whether or not a given manuscript would be suitable for the $\mathrm{Pol}$ Arch Med Wewn in view of our priorities and other articles that are under review.
In 2014, new colleagues were invited to join our Scientific Board (tABle 3). We also bid farewell to Professors Jolanta Kunert-Radek, Józef Małolepszy, Edmund Nartowicz, Janusz Szajewski, and Krzysztof Warzocha, and I would like to express my gratitude for their work and long-term support.

In 2014, the team of the Pol Arch Med Wewn will be working to improve the journal's website and incorporate new features and improvements to existing functionality. We are also planning to introduce a plagiarism detection system to our peer-review process. In our review articles, we intend to be more focused on the summaries of recent scientific and/or clinical advances of importance to internal medicine and related areas of basic science research. Our journal provides a means to advance the broad specialty and this task is genuinely a team effort. Without the involvement of the editors, authors, reviewers, readers, and supporters, it would not be possible to achieve these goals.

At the beginning of the New Year 2014, I would like to wish you all success in your research and look forward to your continued contribution to the Pol Arch Med Wewn as reviewers and as authors.

\section{REFERENCES}

1 Undas A. 2012 impact factor of the Pol Arch Med Wewn: new challeng es and hopes. Pol Arch Med Wewn. 2013; 123: 350-352.

2 Kucharz EJ. The man behind the journal: Editors-in-Chief of the Polish Archives of Internal Medicine (1923-2013). Pol Arch Med Wewn. 2013; 123 : 339-346.

3 Janda K, Krzanowski M, Chowaniec E, et al. Osteoprotegerin as a marker of cardiovascular risk in patients on peritoneal dialysis. Pol Arch Med Wewn. 2013; 123: 149-155.

4 Szpak D, Grochowalski A, Chrząszcz R, et al. Tobacco smoke exposure and endothelial dysfunction in patients with advanced coronary artery disease. Pol Arch Med Wewn. 2013; 123: 474-481.

5 Pietruszyński R, Markuszewski L, Masiarek K, et al. Role of preproce dural glutathione concentrations in the prediction of major adverse cardiac events in patients with acute coronary syndrome treated with percutaneous coronary intervention. Pol Arch Med Wewn. 2013; 123: 228-237.

6 Nehring P, Mrozikiewicz-Rakowska B, Sobczyk-Kopcioł A, et al. Osteoprotegerin gene rs2 073617 and rs3 134069 polymorphisms in type 2 diabetes patients and sex-specific rs2 073618 polymorphism as a risk factor for diabetic foot. Pol Arch Med Wewn. 2013; 123: 176-182.

7 Rechciński T, Jasińska A, Peruga JZ, et al. Presence of coronary collaterals in ST-elevation myocardial infarction patients does not affect long-term outcome. Pol Arch Med Wewn. 2013; 123: 29-37.

8 Sarr MG. 2012 revision of the Atlanta classification of acute pancreatitis. Pol Arch Med Wewn. 2013; 123: 118-124.

9 Sosnowski M, Kozakiewicz K, Syzdół M, et al. Coronary artery calcium in type 2 diabetes: a nested case-control study. Pol Arch Med Wewn. 2013; 123: 38-44.

10 Kamiński MJ, Kamińska M, Skorupa I, et al. In-silico identification of cardiovascular disease-related SNPs affecting predicted microRNA target sites. Pol Arch Med Wewn. 2013; 123: 355-363.

11 Grzebyk E, Knapik-Kordecka M, Piwowar A. Advanced glycation end -products and cathepsin cysteine protease in type 2 diabetic patients. Pol Arch Med Wewn. 2013; 123: 364-370.

12 Pigłowska M, Kostka J, Kostka T. Association between respiratory tract infections and incidence of falls in nursing home residents. Pol Arch Med Wewn. 2013; 123: 371-377. 